\title{
表層 $\mathrm{Nb}-\mathrm{V}$ 添加による熱延鋼板の 疲労限度比の向上
}

\section{橋本 嘉雄 ${ }^{*} \cdot$ 水井 正也 ${ }^{*} \cdot$ 関根 知雄 $^{*}$}

\author{
Improvement of the Ratio of Fatigue Limit to Tensile Strength \\ in Hot Rolled Steel Sheets by the Surface Strengthening
}

Yoshio Hashimoto, Masaya Mizui and Tomoo SeKine

\begin{abstract}
Synopsis :
Plain bending fatigue strength has been investigated about the surface layer strengthened hot rolled steel sheets produced by intercritical rolling of cast composite ingot which in the surface layers, about $0.01 \% \mathrm{Nb}-0.1 \% \mathrm{~V}$ are added on the $0.14 \% \mathrm{C}-0.5 \% \mathrm{Mn}$ base composition. Following results are obtained.

(1) The ratio of fatigue limit to tensile strength becomes as high as about 0.67 in the polished specimens of $20 \%$ surface fraction. This value is very high compared with that of conventional uniform hot rolled steel sheets.

(2) Fatigue limit of the $8 \%$ prestrained specimen is $4 \mathrm{kgf} / \mathrm{mm}^{2}$ lower than that of the non-strained at the $20 \%$ surface fraction. This decrease is caused by very low work-hardening property and residual tension stress in the surface layers.

(3) It is thought that fatigue limit of surface layer strengthened hot rolled steel sheets is determined by that of surface or inner layer at large or small surface fraction each. At this transient region of surface fraction $(10 \sim 20 \%)$, the ratio of fatigue limit to tensile strength becomes maximum.

Key words : fatigue; fatigue limit; plain bending; surface strengthened; niobium; vanadium; intercritical rolling ; precipitation ; dislocation; residual stress.
\end{abstract}

\section{1. 緒言}

自動車では軽量化が進められており，その一手段とし て素材鋼板の厚み減少がある11. ホイールディスクを例 にとると素材鋼板の厚み減少はホイール部品の疲労耐久 性を低下させるので高強度鋼板を使用してこれを補わね ばならない. 乗用車のホイールディスクは板厚約 $3 \sim 4$ $\mathrm{mm}$ の熱延鋼板をプレス，穴明け加工して製造する2). 疲労限度に着目すると, 熱延鋼板の疲労限度 $\left(\sigma_{W}\right)$ と 引張強度 $\left(\sigma_{B}\right)$ の比 $\left(\sigma_{W} / \sigma_{B}\right.$, 以下疲労限度比と呼ぶ $)$ は熱延ままで $0.4 \sim 0.5$ 程度である ${ }^{3)}$. 従つて, 素材鋼 板の疲労限度を高くするには高強度化せざるを得ず，プ レス時の荷重の増加や合金添加量の増加を避けられな い.もし疲労限度比の高い鋼板が得られればそれだけ高 強度化の程度は緩和される. 熱延鋼板の疲労強度の向上 には $\mathrm{Si}, \mathrm{Mn}$ による固溶強化，および $\mathrm{Nb}, \mathrm{V}$ 等による
析出強化が比較的有利であると阿部らは報告してい $る^{4)}$. 近年, プレス成形性が優れ, 疲労限度も高い Dual phase 鋼板が開発されたが, 疲労限度比を飛躍的 に向上させるには至つていない，疲労強度を高くする別 の方法として高周波焼入れ，浸炭，窒化，表面加工によ る表層硬化 ${ }^{5)}$ が良く知られている。しかし，これらの方 法は高価であるか，あるいは，例えば複雑な形状の表面 部分のみに均一に表層硬化を行うのは容易でないなどの 理由のためホイールディスクでは，いまだ使用されてい ない。本田らは異鋼種を熱間圧着させた表層高強度ク ラッド鋼板の疲労強度について検討している6) が，予加 工の影響は明らかにされていない. 彼らはクラッド鋼板 の引張り・圧縮試験における疲労限度に対し, 表層の影 響を考慮した係数を仮定し, 疲労限度が複合比約 0.3 で最も高くなることを示唆している7) がこの点は興味深 い. また, 小林らは引張強度 $60 \mathrm{kgf} / \mathrm{mm}^{2}$ 級のハイテン

昭和 61 年 4 月本会講演大会にて発表 昭和 63 年 4 月 28 日受付 (Received Apr. 28, 1988)

* 新日本製鉄(株)薄板研究センター (Sheet \& Coil Research Lab., Nippon Steel Corp., 1-1-1 Edamitsu Yahatahigashi-ku Kitakyushu 805) 
Table 1. Chemical composition of surface layer strengthened hot rolled steel sheet (Ingot analysis).

\begin{tabular}{|c|c|c|c|c|c|c|c|c|c|}
\hline Layer & $\mathrm{C}$ & $\mathrm{Si}$ & $\mathrm{Mn}$ & $\mathrm{P}$ & $\mathrm{S}$ & $\mathrm{Al}$ & $\mathrm{Nb}$ & V & REM \\
\hline $\begin{array}{l}\text { Surface } \\
\text { Inner }\end{array}$ & $\begin{array}{l}0.16 \\
0.12\end{array}$ & $\begin{array}{l}0.02 \\
0.01\end{array}$ & $\begin{array}{l}0.52 \\
0.46\end{array}$ & $\begin{array}{l}0.004 \\
0.004\end{array}$ & $\begin{array}{l}0.002 \\
0.014\end{array}$ & $\begin{array}{l}0.035 \\
0.026\end{array}$ & $\begin{array}{l}0.009 \\
0.001\end{array}$ & $\begin{array}{l}0.097 \\
0.008\end{array}$ & $\begin{array}{l}0.004 \\
0.001\end{array}$ \\
\hline
\end{tabular}

\begin{tabular}{|c|c|c|c|}
\hline Cast composite ingot & Rough rolling & Finish rolling & Grinding \\
\hline $\begin{array}{l}\text { Alloying in surface layer } \\
\text { Ingot size } \\
150^{t} \times 150^{w} \times 300^{e}(\mathrm{~mm})\end{array}$ & $\begin{array}{l}\text { Reheating: } 1100^{\circ} \mathrm{C}, 1 \mathrm{~h} \\
\text { Finishing thickness : } \\
\qquad 50 \sim 55 \mathrm{~mm}\end{array}$ & $\begin{array}{l}\text { Reheating: } 1100^{\circ} \mathrm{C}, 1 \mathrm{~h} \\
\text { Finishing thickness : } 5 \mathrm{~mm} \\
\mathrm{FT}: 740 \sim 750^{\circ} \mathrm{C}\left(<\mathrm{Ar}_{3}\right)\end{array}$ & $\begin{array}{l}\text { Fraction of } \\
\text { Surface layer } \\
\text { was changed }\end{array}$ \\
\hline
\end{tabular}

Fig. 1. Processing condition.

と $30 \mathrm{kgf} / \mathrm{mm}^{2}$ 級の軟鋼を鋳込み法で接合させた 2 層ク ラッド鋼の片振り引張疲労強度が軟鋼単体の片振り引張 疲労強度より著しく高くなると報告している ${ }^{8)}$.ここで は表層強化鋼板の疲労限度および疲労限度比向上機構を 明らかにし高疲労限度比鋼板を開発するため境界面が完 全に溶着した表層強化熱延鋼板を実験室で製造し, 平面 曲げ疲労特性について調査した。

\section{2. 実 験 方 法}

供試鋼の化学成分を Table 1 に示す. 表層の強度を 内層より高くするため表層に $\mathrm{Nb}$ を約 $0.01 \%, \mathrm{~V}$ を約 $0.1 \%$ 添加した。また，介在物の疲労強度への影響を 小さくするため, 表層の $\mathrm{S}$ 量を少なくし, REM を添加 した . 次に，工程㧍よび製造条件を Fig. 1 に示す. 中抜鋳造法 ${ }^{10)}$ で複合鋼塊を製造したが，表層への合金 添加は表層用溶鋼中に $\mathrm{Nb}$ と V を添加して行つた。一 方, $\gamma \rightarrow \alpha$ 変態温度域圧延による強度の増加が $\mathrm{Nb}$ 鋼は 普通鋼より大きいことを利用し, 表層と内層の強度差を 大きくするため $\gamma \rightarrow \alpha$ 変態温度域まで熱延した。この後 室温まで空冷し，両表層を研磨して表層率を変えた，表 層率は両表層の合計厚みと全厚みの割合とした．表層と 内層間には遷移領域があり，表層率が $0 \%$ の基準はこ の遷移領域の中心付近とした。熱延ままの表層率は約 $40 \%$ であり, 研磨は残留応力の発生を避けるため 1 回 当たりの研磨量を $2 \sim 3 \mu \mathrm{m}$ 以下にした. 研磨後の表面 粗度は 3 4 $\mu \mathrm{m}\left(R_{\text {max }}\right)$ で, 両表層の片側表層率（片側 表層厚みと全厚みの割合）は目標の $3 \sim 5 \%$ 以内であつ た. 疲労試験は熱延後研磨ままおよび研磨後 $8 \%$ （公 称ひずみ）引張予加工の 2 種類の試験片を用いて, シェ ンク式疲労試験機により両振り平面曲げ, 繰返し速度 $3000 \mathrm{cpm}$ で実施した。予加工のない（研磨まま）試験 片は熱延鋼板を所定の表層率に研磨後疲労試験片に加工 した。また， $8 \%$ 引張予加工試験片は熱延鋼板を幅 40 ×長さ $250(\mathrm{~mm})$ の長方形に切断後所定の表層率に研
磨し, $8 \%$ 引張予加工を加えた後疲労試験片に加工し た. ホイールディスクでは熱延鋼板をプレス後使用する ので成形加工品の疲労が問題である.このため, 予加工 の疲労への影響を調査する必要がある. 予加工には引張 り, 圧縮, 曲げ加工等があるが, ここでは, 引張りによ る予加工を行つた。 また, 伸びは均一伸びの範囲内で試 験するため $8 \%$ とした. 本実験の $8 \%$ 予加工は均一伸 びの範囲内にあり, 予加工によるネッキングの発生はな かつた. 研磨後, $8 \%$ 引張予加工後および疲労試験後 の試験片の断面硬度を破面から $2 \mathrm{~mm}$ 近傍（破断しなか つた試験片では長手方向の中心部）で測定した. 研磨ま まおよび $8 \%$ 引張予加工試験片の疲労試験後長手方向 残留応力を破面から 2 $5 \mathrm{~mm}, 1 / 4$ 幅位置（破断しなか つた場合は長さ方向の中心部）で D. O. LEESER らと同

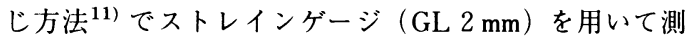
定した．熱延鋼板の圧延方向板厚断面を光学顕微鏡で観 察し，圧延面に平行な表層および内層の微細組織を電子 顕微鏡で観察した．本試験鋼板の疲労試験結果は同等の 引張強さの SAPH 45 の疲労試験結果と比較した.

\section{3. 実 験 結 果}

熱延鋼板の光学顕微鏡組織を Photo. 1 に示す. 表層, 内層とも亜粒界を含むフェライトと亜粒界を含まない フェライトが混合した変態温度域圧延組織となつてい る. 表層率と強度 $\left(\sigma_{B}, \sigma_{Y}(\right.$ 降伏点 $\left.)\right)$ の間には，ほほ 直線関係（Fig. 2) が成立する。これから内層の強度は $\sigma_{B}$ が約 $43 \mathrm{kgf} / \mathrm{mm}^{2}, \sigma_{Y}$ が約 $35 \mathrm{kgf} / \mathrm{mm}^{2}$ である. 表層 の強度は $\sigma_{B}$ が約 $60 \mathrm{kgf} / \mathrm{mm}^{2}, \sigma_{Y}$ が約 $54.5 \mathrm{kgf} / \mathrm{mm}^{2}$ であると外挿法により推測される. 次に疲労試験結果を Fig. 3 に示す。研磨まま試験片は表層率が $10 \%$ で表 層率 $0 \%$ および従来材の SAPH 45 に比べ高い疲労限 度を示す。しかし, 表層率が $10 \%$ から $30 \%$ まで増加 すると疲労限度は $2 \mathrm{kgf} / \mathrm{mm}^{2}$ 増加するが, その増加率 は大きくない. 表層率が $20 \%$ で比較すると $8 \%$ 予加 
Table 2. Fatigue strength of surface layer strengthened and conventional hot rolled steel sheets.

\begin{tabular}{|c|c|c|c|c|c|c|c|}
\hline \multirow{3}{*}{ Steel } & \multicolumn{3}{|c|}{ Hot-rolled } & \multicolumn{4}{|c|}{$8 \%$ prestrained (tension) } \\
\hline & \multirow{2}{*}{$\begin{array}{c}\text { Tensile } \\
\text { strength } \\
\sigma_{B} \\
\left(\mathrm{kgf} / \mathrm{mm}^{2}\right)\end{array}$} & \multirow{2}{*}{$\begin{array}{c}\text { Fatigue } \\
\text { limit } \\
\sigma_{W} \\
\left(\mathrm{kgf} / \mathrm{mm}^{2}\right)\end{array}$} & \multirow{2}{*}{$\begin{array}{c}\text { Fatigue } \\
\text { limit ratio } \\
\sigma_{W} / \sigma_{B}\end{array}$} & \multicolumn{2}{|c|}{$\begin{array}{l}\text { Fatigue strength at } \\
5 \times 10^{5} \text { cycles }\end{array}$} & \multirow{2}{*}{$\begin{array}{c}\text { Fatigue } \\
\text { limit } \\
\sigma_{W t} \\
\left(\mathrm{kgf} / \mathrm{mm}^{2}\right)\end{array}$} & \multirow{2}{*}{$\begin{array}{c}\text { Fatigue } \\
\text { limit ratio } \\
\sigma_{W t} / \sigma_{B}\end{array}$} \\
\hline & & & & $\begin{array}{c}\sigma W_{t_{1}} \\
\left(\mathrm{kgf} / \mathrm{mm}^{2}\right)\end{array}$ & $\sigma_{W t_{1}} / \sigma_{B}$ & & \\
\hline $\begin{array}{l}\text { Surface layer } \\
\text { stengthened } \\
\text { (Surface : 20\%) }\end{array}$ & 46.5 & 31 & 0.67 & 32.5 & 0.70 & 27 & 0.58 \\
\hline $\begin{array}{l}\text { Conventional } \\
\text { (SAPH 45) }\end{array}$ & 48.5 & $\begin{array}{c}25 \\
(22)\end{array}$ & $\begin{array}{c}0.51 \\
(0.45)\end{array}$ & $(33.5)$ & $(0.69)$ & (24) & $(0.49)$ \\
\hline
\end{tabular}

( ) : As hot rolled, the others were polished

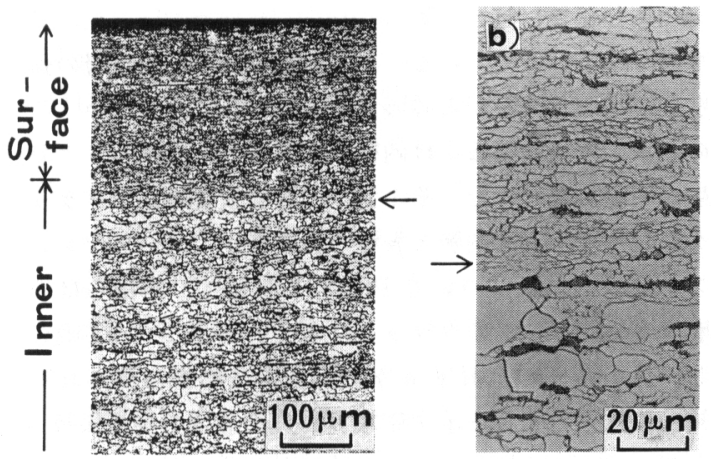

\section{$\leftarrow$ :Surface-inner boundary}

Photo. 1. Microstructure of surface layer strengthened hot rolled steel sheet.

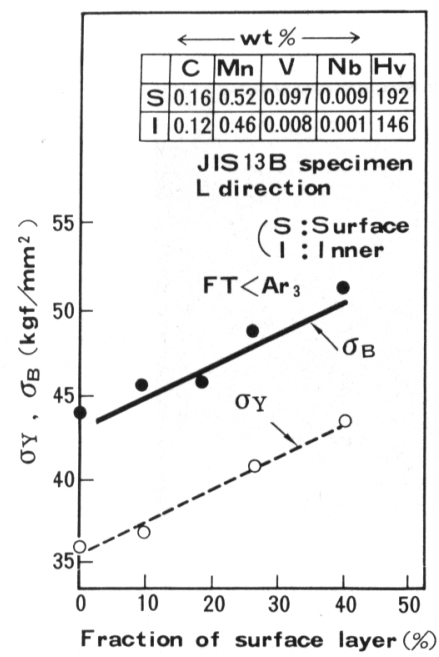

Fig. 2. Relation between tensile properties and fraction of surface layer.

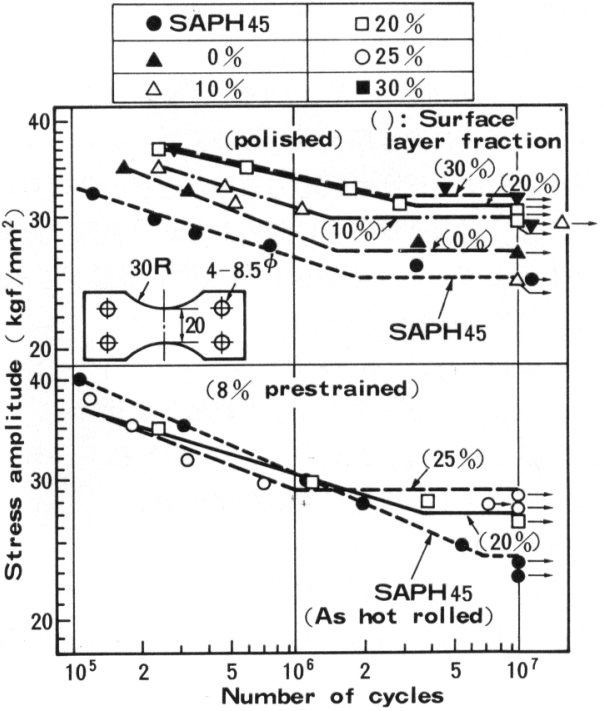

Fig. 3. Fatigue test results of surface layer strengthened hot rolled steel sheets (Fully reversed plain bending).

工試験片は研磨まま試験片より疲労限度が $4 \mathrm{kgf} / \mathrm{mm}^{2}$ 低い。表層強化鋼板および従来の均一鋼板の研磨ままと $8 \%$ 予加工後の引張強度拈よび疲労強度を Table 2 に 示す。研磨ままでは表層強化鋼板の疲労限度比は従来の 均一鋼板の約 0.51 に比し 0.67 と高い。しかし， $8 \%$ 予加工でこの值が 0.58 に低下するが，なお高い水準に ある。

\section{4. 考察}

$4 \cdot 1$ 予加工がない場合（研磨まま）の表層強化鋼板の 疲労限度比

均一鋼板の $\sigma_{W}$ は $\sigma_{B}$ に, ほぼ比例し

$\sigma_{W}=A \times \sigma_{B}$

で表せる ${ }^{3)} . A$ は疲労限度比であり，研磨まま試験片で 
0.5 0.55 程度である.（1 )式と同様の関係が表層強化 鋼板で表層から破壊する場合および内層から破壊する場 合にも適用し得ると仮定すると次の式が成り立つ.

(1)表層から破壊する場合

$$
\sigma_{W S}=A 1 \times \sigma_{B S}
$$

(2)内層から破壊する場合

$$
\sigma_{W I}=A 2 \times \sigma_{B I} /\left(1-R_{S}\right)
$$

$\sigma_{W S}$ : 表層から破壊する場合の疲労限度 $\left(\mathrm{kgf} / \mathrm{mm}^{2}\right)$ $\sigma_{W I}$ : 内層加破壊する場合の疲労限度 $\left(\mathrm{kgf} / \mathrm{mm}^{2}\right)$ $\sigma_{B S}:$ 表層の引張強度 $\left(\mathrm{kgf} / \mathrm{mm}^{2}\right)$ $\sigma_{B I}:$ 内層の引張強度 $\left(\mathrm{kgf} / \mathrm{mm}^{2}\right)$

$R_{S}$ : 表層率（両表層の厚さは同じと仮定する）

$A 1, A 2$ : 定数

( 3 )式の $1 /\left(1-R_{S}\right)$ は表層と内層の境界の応力を平面 曲げ条件で表面に置き換えるための係数である。また， 本試験の疲労限度程度の低応力領域は内層の降伏点以下 であり，曲げ応力とひずみの関係が全板厚範囲で直線関 係にあるとしている，表層強化鋼板の引張強度 $\left(\sigma_{B C}\right)$ はFig. 2 により次式で表せる.

$$
\sigma_{B C}=\sigma_{B I}+\left(\sigma_{B S}-\sigma_{B I}\right) \times R_{S}
$$

従つて, 表層から破壊するときの疲労限度比は

$$
\sigma_{W S} / \sigma_{B C}=A 1 \times \sigma_{B S} /\left(\sigma_{B I}+\left(\sigma_{B S}-\sigma_{B I}\right) \times R_{S}\right) \cdots(5)
$$

内層から破壊するときの疲労限度比は

$$
\begin{array}{r}
\sigma_{W I} / \sigma_{B C}=A 2 \times \sigma_{B I} /\left(1-R_{S}\right) \\
/\left(\sigma_{B I}+\left(\sigma_{B S}-\sigma_{B I}\right) \times R_{S}\right)
\end{array}
$$

となる，各表層率で $\sigma_{W S}, \sigma_{W I}$ のうち小さい方から破壊

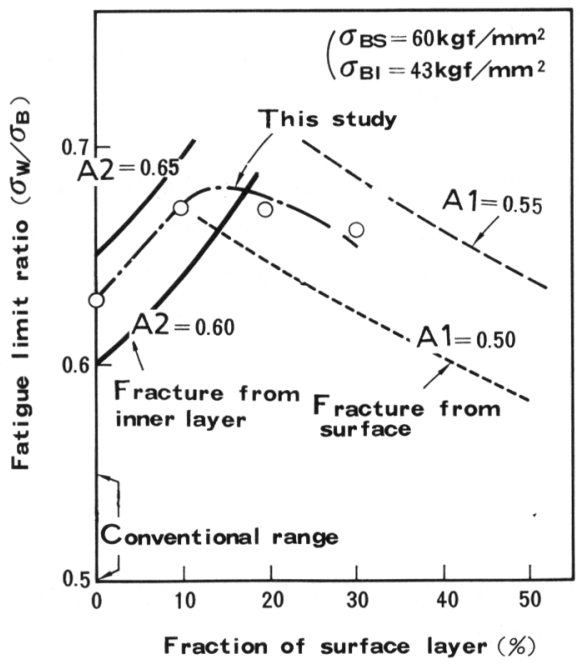

Fig. 4. Relation between fatigue limit ratio and fraction of surface layer of surface layer strengthened hot rolled steel sheets (Polished).
すると考えられる. (5)，（6)式を $A 1=0.5 \sim 0.55$, $A 2=0.6 \sim 0.65$ として図示すると Fig. 4 のようになり, 今回の実験結果と，良く一致する。ここで $A 1<A 2$ と なつているのは内層は表層に覆われていて 2 次元(端部) または 3 次元的に拘束されているのでクラックが発生し にくいためであろう.なお，表層率 $0 \%$ はFig. 6 のご とく表層と内層の遷移領域内を基準とした。このため, 表層率が $0 \%$ の試験片の最表層は内層より硬度が $\mathrm{HV}$ 20 程度高い. 従つてこの実験の表層率が $0 \%$ の鋼板の 疲労限度比は 0.63 となり，均一鋼板の疲労限度比より 高いのであろう。Fig. 4 によると表層率が大きいと表 層から, 表層率が小さいと内層からクラックが発生し, その遷移領域付近の表層率 10 20\% で疲労限度比が最 も高くなると考えられる. 本試験鋼板は内層と表層の強 度差が小さく内層から破壊する表層率の範井が狭い。こ のため, 本試験鋼板では内層の軟質層からのクラック発 生が明瞭でなかつた。そこで，内層の軟質層からクラッ クが発生する例を内層と表層の強度差が大きいステンレ スクラッド鋼板について Photo. 2 に示す. 本田らは表 層率が 30〜75\% のクラッド材の疲労限度について調査 し, 疲労限度の上昇率 $\alpha$ が疲労損傷分布から得られる 補強の効果の割合を示寸係数 $\beta$ と疲労破壊の拘束係数 $\eta$ とで $\alpha=\beta / \eta$ で与えられ, 疲労限度を最大にする最適複 合比が 0.3 程度であると予想した7)。 また, 彼らの提出 した実験式によると疲労限度比を最大にする複合比も 0.3 程度であると推測される. 本試験条件は表層率が $30 \%$ 以下と実験範囲が狭く, 疲労限度が最大となる表 層率は本試験では確認できなかつた。また, 疲労限度比

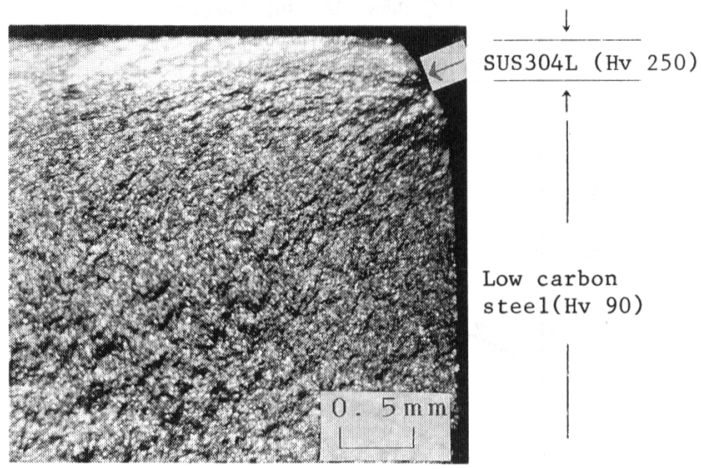

Thickness : $4.2 \mathrm{~mm}$ Surface ratio: $0.12 \sigma: \pm 28 \mathrm{kgf} / \mathrm{mm}^{2} \quad N_{f}$ : $100.55 \times 10^{4}$ Crack initiation : $\leftarrow$

Photo. 2. Optical microstructure after fatigue test in the hot rolled stainless clad steel sheet (Plain bending). 
を最大にする複合比は本試験では $0.1 \sim 0.2$ 程度で本田 らの予想值より小さかつた。この原因として表層と内層 の強度比, 疲労試験方法 (引張り・圧縮と平面曲げ) の 相違，境界内層側の脱炭による軟化の有無等がある。す なわち, 表層と内層の強度比は大きい方が小さい場合よ り, 疲労試験法は引張り・压縮の方が平面曲げの場合上 り (( 3 )式の $1 /\left(1-R_{S}\right)$ の項がなくなるので引張り・ 压縮の方が平面曲げの場合より相対的に内層の疲労強度 が低下する)，境界内層側の脱炭による軟化がある方が 無い場合より疲労限度比が最大となる表層率は大きくな ると考えられる。

\section{$4 \cdot 2$ 予加工がある場合の疲労限度の低下原因}

表層強化熱延鋼板の予加工時の加工硬化特性を Fig. 5 に示す。表層の加工硬化は内層に比し小さい。これは 表層は $\mathrm{Nb} ， \mathrm{~V}$ による析出強化㧍よび変態温度域圧延に よる転位強化（曲粒界強化）が重複しているためである。 表層㧍よび板厚中心の圧延平行面の電子顕微鏡写真を Photo. 3 に示す，表層は内層より転位密度が高い，疲 労試験前後の硬度を比較すると研磨まま試験片の表層硬 度は疲労試験後は試験前に比し HV 10１5 程度高くな る. しかし, $8 \%$ 予加工試験片の表層硬度は疲労試験 前後で同程度である。また，研磨まま試験片と $8 \%$ 予 加工試験片の度労試験後表面付近の硬度は同程度である (Fig. 6)。このことは本試験鋼板では $8 \%$ 予加工によ る表層の硬化が小さく, 疲労強度に対し予加工が有利に ならないことを示唆している. 次に残留応力について検 討する. $8 \%$ 予加工試験片は $27 \mathrm{kgf} / \mathrm{mm}^{2}$ 程度の応力振 幅の疲労試験後で表層に約 $10 \mathrm{kgf} / \mathrm{mm}^{2}$ の引張残留応力 が生じていた (Fig. 7). 疲労試験前の残留応力は表層 と内層の $\sigma_{B}, \sigma_{Y}$ の差と表層率 $20 \%$ から $13 \sim 16$

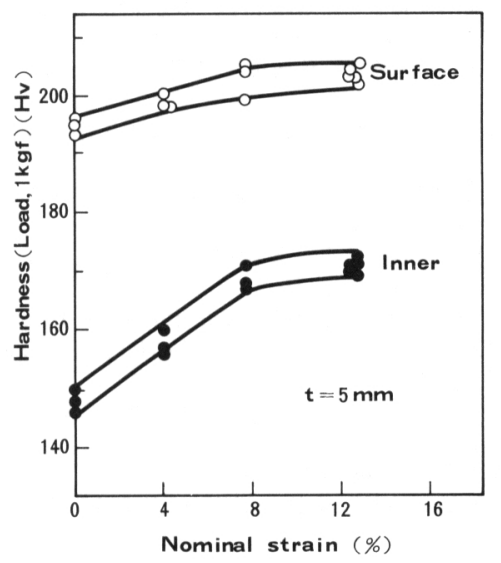

Fig. 5. Work hardening of surface layer strengthened hot rolled steel sheets. $\mathrm{kgf} / \mathrm{mm}^{2}\left(17 \sim 20 \mathrm{kgf} / \mathrm{mm}^{2} \times 0.8\right)$ 程度と推定される. しかし, 以下の検討は実測残留応力により行う。表層強 化鋼板の表層の真破断応力を引張強度の $1.5 \sim 2.0$ 倍

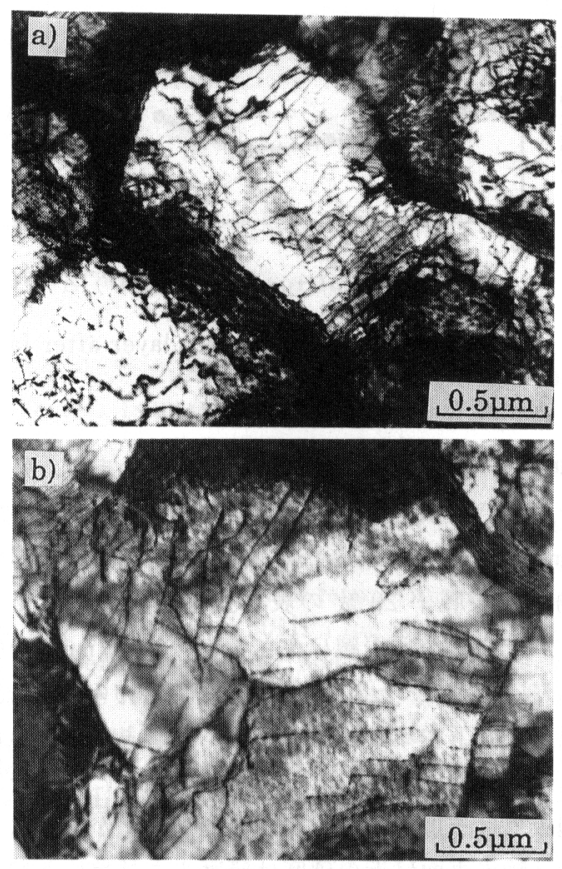

a) Surface layer b) Inner layer

Photo. 3. Transmission electron microstructure of surface layer strengthened hot rolled steel sheet (Parallel to rolling plane).

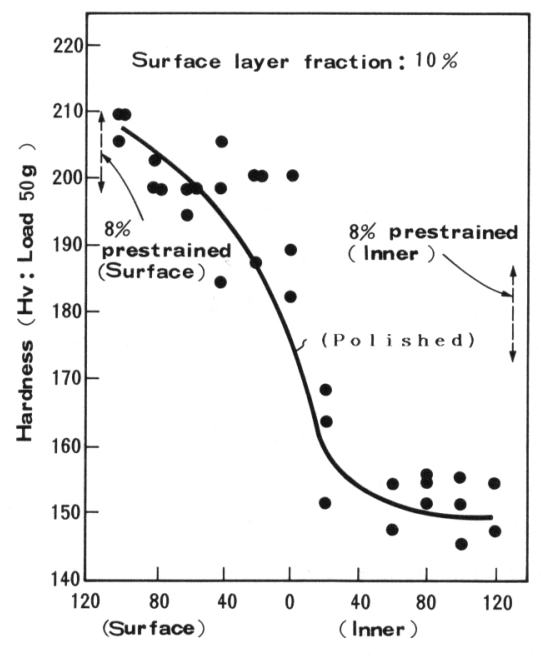

Distance from boundary ( $\mu \mathrm{m})$

Fig. 6. Change of hardness with thickness direction distance from boundary (After fatigue test). 


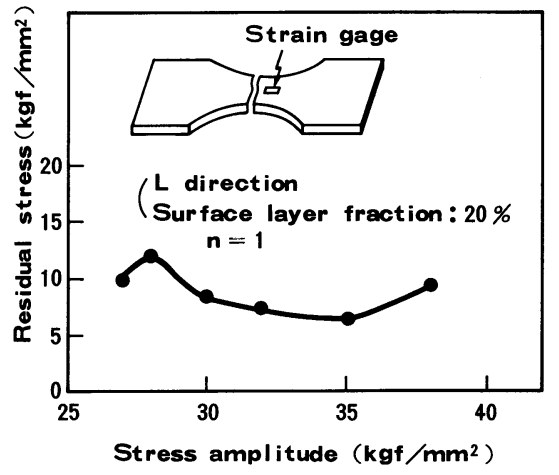

Fig. 7. Residual stress of surface layer after fatigue test ( $8 \%$ prestrained).

（均一鋼板の両者の関係から推定）とし，また，残留応 力のないときの疲労強度は研磨まま試験片と同じの 31 $\mathrm{kgf} / \mathrm{mm}^{2}$ (Table 2) とし, この時の平均応力と応力振 幅の関係を表層率 $20 \%$ の表層強化鋼板について Fig. 8 に示す.これから表層に生じた約 $10 \mathrm{kgf} / \mathrm{mm}^{2}$ の引張 残留応力により $2.5 \sim 3 \mathrm{kgf} / \mathrm{mm}^{2}$ (平均応力の $1 / 3 \sim 1 / 4$ ) 疲労限度が低下すると予測される．研磨まま試験片には 表層に残留応力が発生していない. 本試験に用いた表層 強化鋼板では予加工による表層の加工硬化が非常に小さ く疲労試験後表面付近の硬度は研磨まま試験片と同程度 であつた。一方で，引張残留応力が表層に約 10 $\mathrm{kgf} / \mathrm{mm}^{2}$ 発生していたため表層からの破壊応力が低下 し, 表層率 $20 \%$ の疲労限度（表層からの破壊と推測さ れる）（Fig. 4）が予加工により $4 \mathrm{kgf} / \mathrm{mm}^{2}$ 低下したの であろう。

\section{5. 結 論}

表層に $\mathrm{Nb}$ を約 $0.01 \%, \mathrm{~V}$ を䄪 $0.1 \%$ 添加し, 変態 温度域まで熱延した表層強化熱延鋼板（強度は内層が $\sigma_{B}$ 約 $43 \mathrm{kgf} / \mathrm{mm}^{2}, \sigma_{Y}$ 約 $35 \mathrm{kgf} / \mathrm{mm}^{2}$ であり, 表層は外 挿法により $\sigma_{B}$ 約 $60 \mathrm{kgf} / \mathrm{mm}^{2}, \sigma_{Y}$ 約 $54.5 \mathrm{kgf} / \mathrm{mm}^{2}$ で あると推測される）を試作し，平面曲げ疲労強度につい て調查した。得られた結果は次のとおりである。

(1)研磨まま試験片は表層率が $10 \%$ で表層率 $0 \%$ および従来材の SAPH 45 に比べ高い疲労限度を示す. しかし, 表層率が $10 \%$ から $30 \%$ まで増加すると疲労 限度は $2 \mathrm{kgf} / \mathrm{mm}^{2}$ 増加するが, その増加率は大きくな w.

( 2 ) 熱延後研磨試験片の疲労限度比 $\left(\sigma_{W} / \sigma_{B}\right)$ は表層 率 $20 \%$ では 0.67 と従来の均一鋼板の約 0.51 に比し,

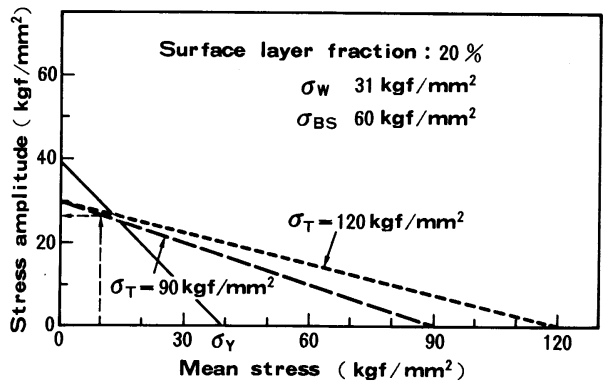

Fig. 8. Fatigue limit diagram.

著しく高い.しかし，8\% 予加工試験片では疲労限度 比は 0.58 に低下する.

( 3 )表層率 $20 \%$ では研磨まま試験片に比し $8 \%$ 予 加工試験片は疲労限度が $4 \mathrm{kgf} / \mathrm{mm}^{2}$ 低下した。表層は $\mathrm{Nb}, \mathrm{V}$ 添加による析出強化および変態温度域圧延によ る転位強化をしているため予加工による加工硬化が小さ い. 一方で引張残留応力が約 $10 \mathrm{kgf} / \mathrm{mm}^{2}$ 発生していた ため表層からの破壊応力が低下し，疲労限度が低下した のであろう

（4)表層強化鋼板は表層率が大きいと表層から，表層 率が小さいと内層からクラックが発生し，その遷移領域 付近の表層率 $(10 \sim 20 \%)$ で疲労限度比が最も高くなり, 内層は 2 次元（端部）または 3 次元的に拘束されている のでクラックが発生しにくく, 内層の疲労限度比 $(A 2)$ は表層の疲労限度比 $(A 1)$ より高いと考えられる.

本研究の遂行に当たり有益なご助言をいただいた新日 本製鉄(株)八幡技術研究部西田新一博士に感謝します.

\section{文献}

1 ) 小森田浩: 塑性と加工, 24 (1983), p. 1193

2 ) 日戸 元, 佐藤泰一, 斎藤 亨, 水井正也, 吉広一秀, 高橋 宏: 鉄と鋼, 68 (1982), p. 1221

3 ）日戸 元, 戸来稔雄, 佐藤泰一: 製鉄研究 (1981) 304, p. 120

4 ）阿部 隆，三瓶哲也，大鈴弘忠，小指軍夫: 鉄と鋼，70 (1984), p. 1459

5 ) 岡本正三: 鉄鋼材料（標準金属工学講座 3 ）（1963）, p. 296 [コロナ社]

6 ) 本田和男, 鳥居太始之, 宮本俊郎: 日本機械学会論文集 (A 編)， 45 (1979), p. 108

7 ) 本田和男, 鳥居太始之: 材料, 23 (1974), p. 40

8 ）奥村健人, 中井揚一, 元田邦昭, 小林邦彦: 圧力技術, 19 (1981), p. 319

9 ）鉄鋼材料便覽（日本金属学会，日本鉄鋼協会編）（1985）, p. 480 [丸善]

10）本田順太郎: 鉄と鋼, 69 (1983), p. 507

11 ) D. O. LEESER and R. A. DAANE: Proc. SESA, 12 (1954), p. 203 